Check for updates

1 Newcastle University, Newcastle upon Tyne, UK

2 Newcastle upon Tyne, UK

Correspondence to: A M Pollock Allyson.Pollock@newcastle.ac.uk

Cite this as: BMJ 2020;371:m4851 http://dx.doi.org/10.1136/bmj.m4851 Published: 21 December 2020

\section{Asymptomatic transmission of covid-19}

\author{
What we know, and what we don't
}

Allyson M Pollock, ${ }^{1}$ James Lancaster ${ }^{2}$

The UK’s £1oobn “Operation Moonshot” to roll out mass testing for covid-19 to cities and universities around the country raises two key questions. How infectious are people who test positive but have no symptoms? And, what is their contribution to transmission of live virus?

Unusually in disease management, a positive test result is the sole criterion for a covid-19 case. Normally, a test is a support for clinical diagnosis, not a substitute. This lack of clinical oversight means we know very little about the proportions of people with positive results who are truly asymptomatic throughout the course of their infection and the proportions who are paucisymptomatic (subclinical), presymptomatic (go on to develop symptoms later), or post-infection (with viral RNA fragments still detectable from an earlier infection).

Earlier estimates that $80 \%$ of infections are asymptomatic were too high and have since been revised down to between $17 \%$ and $20 \%$ of people with infections. ${ }^{12}$ Studies estimating this proportion are limited by heterogeneity in case definitions, incomplete symptom assessment, and inadequate retrospective and prospective follow-up of symptoms, however. ${ }^{3}$ Around $49 \%$ of people initially defined as asymptomatic go on to develop symptoms. 45

It's also unclear to what extent people with no symptoms transmit SARS-CoV-2. The only test for live virus is viral culture. PCR and lateral flow tests do not distinguish live virus. No test of infection or infectiousness is currently available for routine use. ${ }^{6-8}$ As things stand, a person who tests positive with any kind of test may or may not have an active infection with live virus, and may or may not be infectious. 9

The relations between viral load, viral shedding, infection, infectiousness, and duration of infectiousness are not well understood. In a recent systematic review, no study was able to culture live virus from symptomatic participants after the ninth day of illness, despite persistently high viral loads in quantitative PCR diagnostic tests. However, cycle threshold $(\mathrm{Ct})$ values from PCR tests are not direct measures of viral load and are subject to error. ${ }^{10}$

While viral load seems to be similar in people with and without symptoms, the presence of RNA does not necessarily represent transmissible live virus. The duration of viral RNA shedding (interval between first and last positive PCR result for any sample) is shorter in people who remain asymptomatic, so they are probably less infectious than people who develop symptoms. ${ }^{11}$

Viral culture studies suggest that people with SARS-CoV-2 can become infectious one to two days before the onset of symptoms and continue to be infectious up to seven days thereafter; viable virus is relatively short lived. ${ }^{7}$ Symptomatic and presymptomatic transmission have a greater role in the spread of SARS-CoV-2 than truly asymptomatic transmission. ${ }^{1212} 13$

The transmission rates to contacts within a specific group (secondary attack rate) may be 3-25 times lower for people who are asymptomatic than for those with symptoms. ${ }^{121415}$ A city-wide prevalence study of almost 10 million people in Wuhan found no evidence of asymptomatic transmission. ${ }^{16}$ Coughing, which is a prominent symptom of covid-19, may result in far more viral particles being shed than talking and breathing, so people with symptomatic infections are more contagious, irrespective of close contact. ${ }^{17}$ On the other hand, asymptomatic and presymptomatic people may have more contacts than symptomatic people (who are isolating), underlining the importance of hand washing and social distancing measures for everyone.

\section{Missed opportunity}

By failing to integrate testing into clinical care, we have missed an important opportunity to better understand the role of asymptomatic infection in transmission. Given the variation in prevalence and testing strategies by region, the proportions of people with positive and negative test results should be published alongside the purpose of the testing strategy and the population tested (screening healthy populations in schools, universities, and health and social care, or testing people with symptoms). Government regulations on recording the age, ethnicity, sex, and place of residence of people with positive results must also be followed. ${ }^{18}$

Searching for people who are asymptomatic yet infectious is like searching for needles that appear and reappear transiently in haystacks, particularly when rates are falling. ${ }^{19}$ Mass testing risks the harmful diversion of scarce resources. A further concern is the use of inadequately evaluated tests as screening tools in healthy populations. ${ }^{20}$

The UK's testing strategy needs to be reset in line with the Scientific Advisory Group for Emergencies' recommendation that "Prioritising rapid testing of symptomatic people is likely to have a greater impact on identifying positive cases and reducing transmission than frequent testing of asymptomatic people in an outbreak area." ${ }^{11}$

Testing should be reintegrated into clinical care with clinical and public health oversight and case definitions based on clinical diagnosis. Carefully designed prospective studies of cases and contacts are needed to estimate transmission rates by people 
with and without symptoms. These should include careful investigations of outbreaks-for example, testing all contacts of people with a clear history of exposure, especially in high risk environments such as nursing homes, prisons, and other institutional settings.

Coronavirus infection surveys by the Office for National Statistics ${ }^{22}$ and the REACT survey ${ }^{23}$ could be expanded to include clinical follow-up of participants combined with tests of viral load and viral cultures. The absence of strong evidence that asymptomatic people are a driver of transmission is another good reason for pausing the roll out of mass testing in schools, universities, and communities.

Competing interests: We have read and understood BMJ policy on declaration of interests. AP was a member of independent SAGE.

Provenance and peer review: Not Commissioned; externally peer reviewed.

1 Buitrago-Garcia D, Egli-Gany D, Counotte MJ, etal. Occurrence and transmission potential of asymptomatic and presymptomatic SARS-CoV-2 infections: a living systematic review and meta-analysis. PLoS Med 2020;17:e1003346.

doi: 10.1371/journal.pmed.1003346 pmid: 32960881

2 Byambasuren O, Cardona M, Bell K, Clark J, McLaws M-L, Glasziou P. Estimating the extent of asymptomatic COVID-19 and its potential for community transmission: systematic review and meta-analysis. J Association of Medical Microbiology and Infectious Disease Canada, 2020

3 Meyerowitz EA, Richterman A, Bogoch II, Low N, Cevik M. Towards an accurate and systematic characterisation of persistently asymptomatic infection with SARS-CoV-2. Lancet Infect Dis 2020;S1473-3099(20)30837-9.pmid: 33301725

4 He J, Guo Y, Mao R, Zhang J. Proportion of asymptomatic coronavirus disease 2019: A systematic review and meta-analysis. J Med Virol 2020. doi: 10.1002/jmv.26326 pmid: 32691881

5 Yanes-Lane M, Winters N, Fregonese F, etal. Proportion of asymptomatic infection among COVID-19 positive persons and their transmission potential: A systematic review and meta-analysis. PLoS One2020;15:e0241536. doi: 10.1371/journal.pone.0241536 pmid: 33141862

6 Beale S, Hayward A, Shallcross L, Aldridge RW, Fragaszy E. A rapid review and meta-analysis of the asymptomatic proportion of PCR-confirmed SARS-CoV-2 infections in community settings. Wellcome Open Research. 05 Nov 2020doi: 10.12688/wellcomeopenres.16387.1

7 Cevik M, Tate M, Lloyd O, Maraolo AE, Schafers J, Ho A. SARS-CoV-2, SARS-CoV, and MERS-CoV viral load dynamics, duration of viral shedding, and infectiousness: a systematic review and meta-analysis. Lancet Microbe 2020doi: 10.1016/S2666-5247(20)30172-5

8 Deeks JJ, Brookes AJ, Pollock AM. Operation Moonshot proposals are scientifically unsound. BMJ 2020;370:m3699. doi: 10.1136/bmj.m3699 pmid: 32963111

9 Centers for Disease Control and Prevention. Coronavirus disease 2019 (COVID-19) 2020 interim case definition. 5 Aug 2020. https:/wwwn.cdc.gov/nndss/conditions/coronavirus-disease-2019covid-19/case-definition/2020/08/05/

10 Dahdouh E, Lázaro-Perona F, Romero-Gómez MP, Mingorance J, García-Rodriguez J. Ct values from SARS-CoV-2 diagnostic PCR assays should not be used as direct estimates of viral load. J Infect 2020;S0163-4453(20)30675-7. pmid: 33131699

11 Walsh KA, Jordan K, Clyne B, etal. SARS-CoV-2 detection, viral load and infectivity over the course of an infection. J Infect 2020;81:357-71. doi: 10.1016/j.jinf.2020.06.067 pmid: 32615199

12 Qiu X, Nergiz Al, Maraolo AE, Bogoch II, Low N, Cevik M. Defining the role of asymptomatic and pre-symptomatic SARS-CoV-2 transmission: a living systematic review.medRxiv. 2020 Oct 06;2020.09.01.20135194. [Preprint.] https://www.medrxiv.org/content/10.1101/2020.09.01.20135194V2

13 Cevik M, Kuppalli K, Kindrachuk J, Peiris M. Virology, transmission, and pathogenesis of SARS-CoV-2. BMJ 2020;371:m3862. doi: 10.1136/bmj.m3862 pmid: 33097561

14 Madewell ZJ, Yang Y, Longini IM, JrHalloran ME, Dean NE. Household transmission of SARS-CoV-2: a systematic review and meta-analysis of secondary attack rate. JAMA Netw Open 2020;3:e2031756. doi: 10.1001/jamanetworkopen.2020.31756 pmid: 33315116

15 Koh WC, Naing L, Chaw L, etal. What do we know about SARS-CoV-2 transmission? A systematic review and meta-analysis of the secondary attack rate and associated risk factors. PLoS One 2020;15:e0240205. doi: 10.1371/journal.pone.0240205 pmid: 33031427

16 Cao S, Gan Y, Wang C, etal. Post-lockdown SARS-CoV-2 nucleic acid screening in nearly ten million residents of Wuhan, China. Nat Commun 2020;11:5917. . doi: 10.1038/s41467-020-19802-w pmid: 33219229

17 Chen PZ, Bobrovitz N, Premij Z, Koopmans M, Fisman DN, Gu FX. Heterogeneity in transmissibility and shedding SARS-CoV-2 via droplets and aerosols.medRxiv 2020. [Preprint.] doi: 10.1101/2020.10.13.20212233

18 Health Protection (Notification) Regulations. 2010. https://www.legislation.gov.uk/uksi/2010/659/regulation/4

19 Mahase E. Covid-19: Universities roll out pooled testing of students in bid to keep campuses open. BMJ 2020;370:m3789. https://www.bmj.com/content/370/bmj.m3789/rr-0. doi: 10.1136/bmj.m3789 pmid: 32994203

20 Deeks JJ, Raffle AE. Lateral flow tests cannot rule out SARS-CoV-2 infection. BMJ2020;371:m4787. doi: 10.1136/bmj.m4787 pmid: 33310701
21 SAGE 56th meeting on covid-19, 10 Sep 2020. https://assets.publishing.service.gov.uk/government/uploads/system/uploads/attachment_data/file/928699/S0740_Fifty-sixth_SAGE_meeting_on_Covid-19.pdf

22 Office for National Statistics. Coronavirus (COVID-19) Infection Survey, UK. https://www.ons.gov.uk/peoplepopulationandcommunity/healthandsocialcare/conditionsanddiseases/bulletins/coronaviruscovid19infectionsurveypilot/11december2020

23 Imperial College London. Real-time Assessment of Community Transmission (REACT) Study. https://www.imperial.ac.uk/medicine/research-and-impact/groups/react-study/

This article is made freely available for use in accordance with BMJ's website terms and conditions for the duration of the covid-19 pandemic or until otherwise determined by BMJ. You may use, download and print the article for any lawful, non-commercial purpose (including text and data mining) provided that all copyright notices and trade marks are retained. 